\title{
Dividend Taxation: The Comparative Analysis with Emphasis on Slovenia and Croatia
}

UDK: $336.2(497.12: 497.13)$

\author{
Helena Blažić \\ University of Rijeka, Faculty of Economics \\ helena@fri.hr \\ Dženeta Bašagić \\ University of Rijeka, Faculty of Economics \\ dzenetabas @yahoo.com
}

\begin{abstract}
The paper presents and analyses different corporate tax systems (methods of integration of corporate and personal income tax). The comparative and dynamic analysis shows that schedular treatment gains in importance. Particular attention is given to Slovenia and Croatia, which has just modified its system of separate tax rate for dividends. Now both countries have the dividend exemption method the former a partial and the later a full method. The measurement of the dividend relief shows that this benefit is distributed regressively in both of the countries.
\end{abstract}

Keywords: economic double taxation, dividends, corporate tax, personal income tax, regressivity

\section{Introduction}

The usual problem concerning combined corporate and personal income tax treatment of distributed profits (dividends) - their double taxation can be mitigated or eliminated through some of the forms (methods) of integration of corporate and personal income tax.

The paper will analyze this combined treatment (also called "corporate tax system") in general and establish its development trends in the EU countries (taking into account the situation in the other developed countries too) and SEE countries, including Turkey, as EU candidate country.

The degree of mitigation of double taxation (dividend relief) in the form of (partial) dividend exemption will be calculated for Croatia and Slovenia. Its effects, 
Helena Blažić, Dženeta Bašagić

Dividend Taxation: The Comparative Analysis with

Emphasis on Slovenia and Croatia

common to the all countries that use this method, will be analyzed in further and compared to the effects of other methods used.

The paper will try to support the theses about the regressive impact of the analyzed method, its dynamic predominance, as well as the dilution of the standard classification of the integration methods.

\section{Corporate tax systems}

The term "corporate tax systems" usually denotes different relationships and integration levels between corporate income tax and personal income tax on dividends, paid by shareholders. As known, corporate income is taxed first at the corporate level and then again at the shareholder level, due to the taxation of dividends (income tax) at the shareholder's marginal income tax rate.

This phenomenon (economic double taxation of dividends) could be mitigated or even eliminated /avoided in a different ways. Figure 1 describes different forms of corporate tax systems.

Figure 1: Forms of relationship between corporation tax and income tax of shareholders

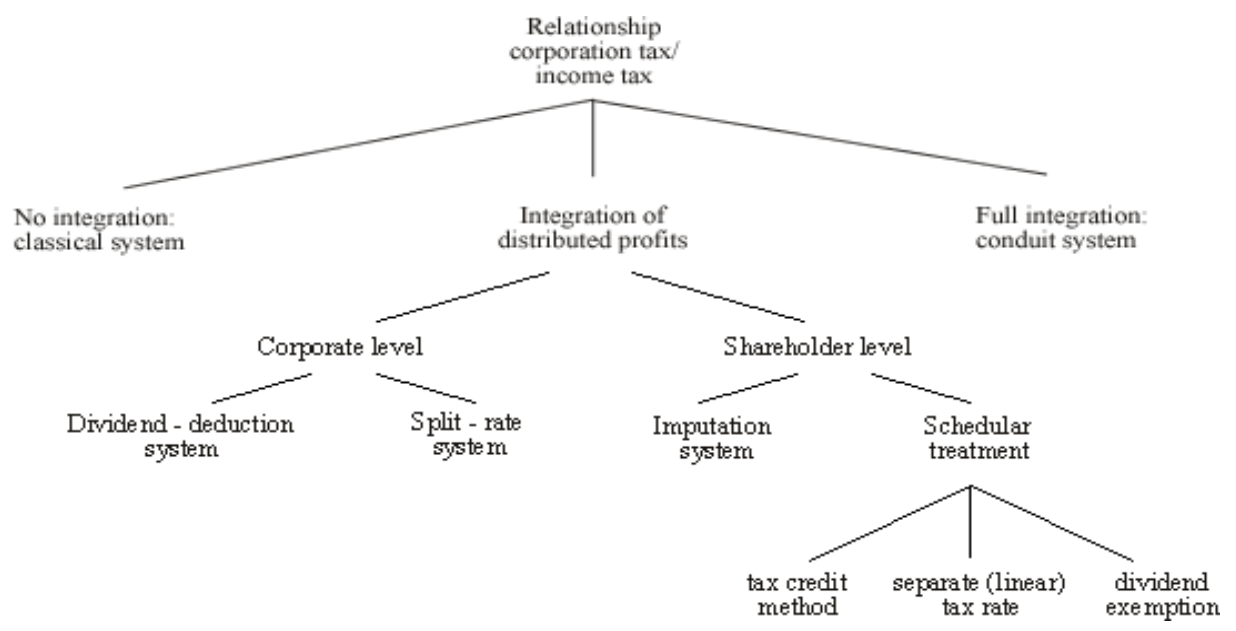

Source: authors addition to Cnossen, 1993, p.4

Classical system and full integration are two extreme positions. The former treats corporations as being completely separated from their shareholders. This means that corporate income tax and after that personal income tax (if profits are distributed to the shareholders in the form of dividends) are fully 


\section{Helena Blažić, Dženeta Bašagić \\ Dividend Taxation: The Comparative Analysis with Emphasis on Slovenia and Croatia}

applied (economic double taxation). Proponents of such a system point out that the shareholders are completely divided from their (big) corporation (ownership and control functions are not integrated) and that they do not have any influence on profits, but only get dividends when they are declared by management. Such a system gives an incentive to retain profits, instead of distributing them to shareholders, since the later results in a full income tax burden of shareholders (in addition to corporate tax burden).

The later (full integration) means complete integration of corporate and personal income tax. The corporate income tax is treated as withholding tax that is later completely credited from the personal income tax regardless whether profits are distributed or not. Since the effect is the same as with business entities paying personal (and not corporate) income tax, this form is also called partnership method. There is no economic double taxation here at all. Although this form is closest to the theoretical norms of $\mathbf{S}-\mathrm{H}-\mathrm{S}^{\mathbf{1}}$ income concept, it has been never implemented in practice, maybe mostly due to its negative fiscal effects, relatively complicated procedure, but also the fact that the shareholders might have to pay income tax, although no dividends have in fact been received.

So, only distributed profits are taken into account for integration. The relief can be given either at corporate or at shareholder level.

At the corporate level, dividend relief can take the form of the dividenddeduction system or split rate. In the former case distributed profits - dividends are deducted from the taxable profits. If that is done in full, the elimination of double taxation is present. If it is done only for the part of distributed profits, the mitigation of double taxation is present. Under the split-rate system, distributed profits are taxed at a lower rate than retained profits. A drawback of this system is that relief is automatically distributed to foreign shareholders, but its final objection is that corporation tax cannot serve as a means to verify the correct return of dividend income for the income tax (Cnossen, 1993, p. 8). Next chapter shows that these systems are not in effect anymore.

The reliefs at shareholder level can be divided into the imputation system and various schedular treatments. All the dividend reliefs at shareholder level, unlike these on the corporate level, promote profit distributions in order to stimulate stock markets.

Imputation system is similar to the full integration, but regarding distributed profits only. Again, it enables for dividends to be taxed at marginal rate of personal income tax only, because the corporate tax paid on distributed profits is

1 Schanz, Haig and Simons 
Helena Blažić, Dženeta Bašagić

Dividend Taxation: The Comparative Analysis with

Emphasis on Slovenia and Croatia

treated as withholding tax. So, the relatively complicated technique of grossing up of dividends (allowing for the corporate tax) and later deducting tax credit of the same amount is applied.

Schedular treatments do not take corporate income tax into account, but have a preferential treatment for dividends in comparison with other forms of personal income ${ }^{2}$. There are three methods that could be used here: tax credit, separate (lower, linear, flat) rate for dividends and dividend exemption.

Tax credit is deducted from personal income tax on dividends, but without former grossing up of these dividends, as in the case of imputation system. This tax credit, as already outlined, is not directly connected with the amount of corporate tax previously paid.

Separate tax rate of dividends is an easier and simpler method. It is usually done by applying final withholding tax on dividends, which rate is, of course, relatively low (for instance the lowest marginal tax rate of personal income tax $)^{3}$. Alternatively and rarer two lower rates could be used, with the dividend income included in the tax return.

The simplest solution is the $100 \%$ (full) dividend exemption (it is equal to zero tax rate on dividends). Here the elimination of economic double taxation is achieved, but with the final tax burden for shareholders being corporate income tax and not personal income tax (its relevant marginal) rate ${ }^{4}$. Dividend exemption could also be partial (only part of the dividends is exempt).

\section{Development trends and current situation - comparative analysis}

The trends in the developed countries have been changing (Messere, 1999, Blažić 2002, IBFD, 2005). In the fifties and early sixties when selffinancing was considered a more reliable route to growth, most countries used the classical system. This view has been challenged in the sixties with the

2 Due to no direct connection of the dividend relief and corporate tax previously paid, the schedular treatment is also claimed to be a classical system (IBFD, 2005 and all previous years of the "European Tax Handbook") or at least modified classical system (Messere, 1993, p. 345).

3 This is mostly accompanied by the option of taxpayers to include dividend income in taxable income (income tax return) if it suits them (for incomes where marginal tax rate is lower than the rate on dividends or the incomes that are lower than the personal allowance (zero rated first bracket)). In that case they choose, in effect, the classical system.

4 In the case of rate of corporate income tax being the same as the (marginal) rate of personal income tax (for instance in the case of a flat tax, where both taxes have the same rate) this problem does not arise. 


\section{Helena Blažić, Dženeta Bašagić \\ Dividend Taxation: The Comparative Analysis with Emphasis on Slovenia and Croatia}

recognition of the problem of double dividend taxation and the need for its mitigation/elimination. In the seventies and eighties the countries introduced integration systems mostly at the shareholder level. The most used form was the imputation system, which was also proposed in the 1975 for the entire EC (but this proposal was never accepted and finally abandoned in 1990).

The reliefs at the corporate level were diminishing and were finally history at the end of the nineties ${ }^{\mathbf{5}}$. Inside the reliefs at the personal level, at the end of the eighties the trend started towards schedular treatment ${ }^{6}$. The transition economies have never even tried to adopt complicated imputation systems and have at the beginning predominantly chosen separate (linear, flat, lower rate) tax, which has an advantage of simplicity, but also fits into latest trends of linear taxation of capital income in general. The same trend towards the separate tax rate was observed in the developed countries in the end of the nineties and at the beginning of the new century. Even the USA, one of the most stubborn classical system countries, moved in that direction.

In the last couple of years, an obvious trend towards dividend exemption in both groups of the countries is observed ${ }^{\mathbf{7}}$. In general, this exemption is more generous in the new EU members (EU 10) and SEE countries, than in old EU members (EU 15), as can be seen from the Tables 1 and $2 .^{\mathbf{8}}$

Now, more than ever, schedular systems, that were earlier mostly present in the transition countries, are now starting to be predominant in the EU, too (Table 1). Among them, separate tax rate and exemption are relatively of the same importance, with the tax credit not to be present anymore. The exemption is mostly partial.

However, since trends in the preferential taxation of capital income (especially dual income tax and linear taxation of one or more of capital incomes) have been gaining in importance, it is difficult to classify some systems with flat (one or even two) dividend tax rate. Formally, it is a schedular system, but since other capital incomes could be taxed in the same way (with same rates), it is somehow closer to the classical system, the more capital incomes

5 Iceland abolished the dividend-deduction system in 1999, and Germany the split-rate system in 2000.

6 This trend is especially pronounced now, with Finland and France leaving full imputation system in 2005, Italy in 2004 and Portugal in 2003

7 Not only some transition countries, among them recently Croatia, but also Germany, France, Italy and Portugal recently moved to that system.

8 Tables cover, as usual for this presentation, only tax treatment of domestic-source dividends paid to resident shareholders. 
Helena Blažić, Dženeta Bašagić

Dividend Taxation: The Comparative Analysis with

Emphasis on Slovenia and Croatia

being taxed at same rates. So, the Netherlands and Sweden could have been said to have a classical system too ${ }^{\text {. }}$.

Table 1: Corporate tax systems in EU 15, Switzerland, Norway, US and Canada in 2005

\begin{tabular}{|c|c|c|c|}
\hline \multicolumn{2}{|r|}{ CLASSICAL SYSTEM } & \multicolumn{2}{|c|}{ IMPUTATION SYSTEM } \\
\hline \multicolumn{2}{|l|}{ Ireland } & \multicolumn{2}{|c|}{ Canada (partial, modified) } \\
\hline \multicolumn{2}{|c|}{ Switzerland (most cantons) } & \multicolumn{2}{|c|}{$\begin{array}{l}\text { Norway (full), but will be replaced with exemption in } \\
2006 \text { (an amount equal to a risk-free return on the } \\
\text { invested capital will be exempt from tax) }\end{array}$} \\
\hline & & \multicolumn{2}{|l|}{ Spain (partial) } \\
\hline & & \multicolumn{2}{|c|}{ United Kingdom (partial), see also under A } \\
\hline \multicolumn{4}{|c|}{ SCHEDULAR SYSTEMS: } \\
\hline \multicolumn{2}{|c|}{ A) Separate (reduced) rate } & \multicolumn{2}{|c|}{ B) Dividend exemption } \\
\hline Country & Rate & Country & Rate \\
\hline Austria & $25 \%$ & Finland & $\begin{array}{l}\text { - for quoted companies: } 43 \% \text { in } \\
2005, \text { later } 30 \% \\
\text { - for non-quoted companies: } \\
\text { 100\% subject to limitation } \\
\end{array}$ \\
\hline Belgium & $25 \%$ & France & $50 \%$ \\
\hline Denmark & $\begin{array}{l}28 \% \text { for dividends not exceeding } \\
D K K 43,300) \\
43 \% \text { on any excess }\end{array}$ & Luxembourg & $50 \%$ \\
\hline Italy & $\begin{array}{l}12,5 \% \text { for smaller shareholders, } \\
\text { see also under } B\end{array}$ & Greece & $100 \%$ \\
\hline Netherlands & $\begin{array}{l}30 \% \text { - in effect classical system }{ }^{3} \\
25 \% \text { for substantial shares }\end{array}$ & Germany & $50 \%$ \\
\hline Sweden & $\begin{array}{l}30 \% \text { - in effect classical system }{ }^{3} \text {, } \\
\text { see also under B }\end{array}$ & Italy & $\begin{array}{l}60 \% \text { for substantial sharehold- } \\
e r s^{2}, \text { see also under } A\end{array}$ \\
\hline $\begin{array}{l}\text { United } \\
\text { Kingdom }\end{array}$ & $\begin{array}{l}10 \% \\
32 \% \text { for higher incomes, see also } \\
\text { under Imputation }\end{array}$ & Portugal & $50 \%$ \\
\hline US & $\begin{array}{l}15 \% \text { (5\% for taxpayers in } 10 \% / \\
15 \% \text { bracket) }\end{array}$ & $\begin{array}{l}\text { Sweden: for } \\
\text { SMEs: }\end{array}$ & $\begin{array}{l}70 \% \text { interest rate on govern- } \\
\text { ment borrowing multiplied by } \\
\text { acquisition value of shares, see } \\
\text { also under } A\end{array}$ \\
\hline
\end{tabular}

${ }^{1}$ Finland: $30 \%$ (43\% in 2005) of dividends from a quoted company is exempt, with the remaining $70 \%$ ( $57 \%$ in 2005 ) being taxed as the shareholder's income from capital (at $28 \%$ ). For dividends from a nonquoted company, dividends representing an annual yield of up to $9 \%$ of the mathematical value of the shares (established for net wealth tax purposes) are fully exempt up to EUR 90,000 per shareholder per year. Thirty per cent (43\% in 2005) of such dividends exceeding EUR 90,000 (subject to the $9 \%$ yield ceiling) is exempt, with the remaining $70 \%$ (57\% in 2005) being taxed as the shareholder's income from

9 The final decision by the authors to classify them into the schedular system was also influenced by Jacobs, et al. (2003, p. 9). 


\title{
Helena Blažić, Dženeta Bašagić \\ Dividend Taxation: The Comparative Analysis with Emphasis on Slovenia and Croatia
}

\begin{abstract}
capital (at $28 \%$ ). Finally, $30 \%$ of any dividend receipts in excess of the $9 \%$ yield ceiling is exempt, with the remaining $70 \%$ (57\% in 2005) being taxed as the shareholder's earned income (at progressive rates).

${ }^{2}$ Italy from 2004: 60\% exemption for individual shareholders, who hold the participation in a business capacity. Individual shareholders not holding the participation in a business capacity are also entitled to the $60 \%$ exemption if they own more than $2 \%$ of the voting power or $5 \%$ of the capital in listed companies, or more than $20 \%$ of the voting power or $25 \%$ of the capital in other companies (substantial participation). Otherwise, dividends derived by individuals are subject to a final withholding tax at a rate of $12.5 \%$.

${ }^{3}$ Since the Netherlands and Sweden tax (almost) all capital income at the same rate $(30 \%)$ as a result of dual tax system in Sweden and almost dual in the Netherlands, their systems are in effect classical systems (not taking into account another tax on dividends from substantial shares of $25 \%$ in the Netherlands and $70 \%$ exemption for SMEs in Sweden) and could be also classified in that way. The Netherlands has another specific feature - the taxation of savings and investment income is based on a deemed yield on assets.
\end{abstract}

Source: Authors classification and synthesis from IBFD: European Tax Handbook, 2005

In effect, the trends of linearity in the capital income taxation have weakened the solid basis of this classification. It could be even argued that if some other capital incomes are taxed at flat rates, but harder than dividends, it is still separate rate system for dividends; if they are taxed at the same rate as dividends, then the real problem (described above) rises. It is relatively often for EU countries to tax dividends in a two separate way or even combine two methods. UK combines reduced rates and partial imputation system. ${ }^{\mathbf{1 0}}$ Besides separate rate, Italy has an exemption for substantial shareholders too.

Sweden has similar preferential tax treatment for the SMEs. Finland, Denmark and the Netherlands distinguish shareholders' investment/yield/participation also, but inside the same method. The UK, additionally, puts higher rate for higher incomes.

As obvious from the Table 2, new EU members and SEE (Turkey is also included here since it is and EU Candidate country) apply either linear tax rate for dividends or their exemption. The only exception is Malta, due to its imputation system, inherited from the former UK system. ${ }^{11}$

The same problem of classification, pointed out in the Table 1 is present even here in the case of Lithuania, that has in effect dual income tax too, so it could be classified in a classical system.

It could be also said, that a full dividend exemption is relatively more used for this group of the countries.

10 Germany had a combination of split rate system (corporate level relief) and imputation system (shareholder level relief) until 2000.

11 The Maltese tax system has its origins in the former British system (until 1965). There is no separate system of corporation tax, and a company is subject to income tax in much the same way as an individual. A full imputation system is used. 
Helena Blažić, Dženeta Bašagić

Dividend Taxation: The Comparative Analysis with

Emphasis on Slovenia and Croatia

Table 2: Corporate tax systems in EU 10, SEE and Turkey in 2005

\begin{tabular}{|c|c|c|c|}
\hline \multicolumn{2}{|c|}{ Separate tax rate } & \multicolumn{2}{|r|}{ Exemption } \\
\hline Country & Rate & Country & Rate \\
\hline Albania & $10 \%$ & Croatia & $100 \%$ from 2005 \\
\hline Bulgaria & $7 \%$ & Estonia & $100 \%{ }^{\prime}$ \\
\hline $\begin{array}{l}\text { Bosnia and } \\
\text { Herzegovina }\end{array}$ & $\begin{array}{l}\min .10-20 \%, \text { possible additional } \\
10-20 \%^{2}\end{array}$ & Latvia & $100 \%$ \\
\hline Croatia & $\begin{array}{l}15 \% \text { - only in } 2005 \text { for dividends } \\
\text { out of distributed profits from } \\
2004\end{array}$ & Macedonia & $50 \%$ \\
\hline Czech Republic & $15 \%$ & $\begin{array}{l}\text { Serbia and } \\
\text { Montenegro: }\end{array}$ & $\begin{array}{l}\text { Serbia } 50 \% \text { (but a rate on } \\
\text { capital income is } 20 \% \text { in com- } \\
\text { parison with the flat rate on } \\
\text { other income }(10 \%)) \text { - in effect } \\
\text { classical system }\end{array}$ \\
\hline Hungary & $\begin{array}{l}20 \% \text { on } 30 \% \text { of the dividends, } \\
35 \% \text { on the remaining } 70 \%\end{array}$ & Slovak Republic & $100 \%$ \\
\hline Lithuania & $\begin{array}{l}15 \% \text { - in effect classical } \\
\text { system }\end{array}$ & Slovenia & $35 \%$ \\
\hline Poland & $19 \%$ & Turkey & $50 \%$ \\
\hline Romania & $10 \%$ & & \\
\hline $\begin{array}{l}\text { Serbia and } \\
\text { Montenegro: }\end{array}$ & $15 \%$ & & \\
\hline \multicolumn{4}{|c|}{ Imputation system: } \\
\hline & & & \\
\hline
\end{tabular}

' Dividends are fully exempt at a shareholder level, but there is a corporate income tax at corporate level. That means that retained profits are completely tax exempt and that only distributed profits are taxed at the corporate level. The "distribution tax" is levied at a rate of 26/74 (approximately $35.14 \%$ ) of the net amount of the profit distribution ( $26 \%$ on the gross amount (distribution + distribution tax) of the distribution.

${ }^{2}$ The exact amount of dividend tax depends on the municipalities (only minimum rates stated); additional tax if all incomes exceed yearly ceiling.

Source: Authors classification and synthesis from IBFD. (2005): European Tax Handbook, Džafić, M.(2004): Oporezivanje dohotka fizičkih lica u F BiH; http://www.nn.hr: Croatian Income Tax Act, 2004 


\section{Helena Blažić, Dženeta Bašagić \\ Dividend Taxation: The Comparative Analysis with Emphasis on Slovenia and Croatia}

\section{Dividend taxation in Slovenia and Croatia}

Slovenia and Croatia both use the dividend exemption method.

It seems that the Slovenian choice was influenced by the German model, where only half of the dividends received are taxable in the hand of the shareholders. Slovenia has slightly strengthened this relief, since the exempt amount was previously $40 \%$ and now $35 \%$. The dividend taxation technique is a little bit more complicated than in Croatia. Dividends are first subject to a provisional $25 \%$ withholding tax levied on the gross amount. Annually dividends are aggregated with income from other categories; the taxable base is calculated by grossing up the amount of dividends received by the amount of withholding tax, less $35 \%$. The tax withheld is creditable against the annual tax liability on aggregate income (IBFD, 2005). From 2006 dividends (together with capital gains and interests) will be taxed with separate tax rate $20 \%$ (as withholding and final tax).

In Croatia the former system of separate (lower) tax rate $(15 \%+$ local surcharge, if any), which was realized simple by the way of final withholding tax, is replaced by the full exemption in 2005. Still, dividends that are paid to resident shareholders out of last year's profits are still treated in the former way. Furthermore, the new full exemption system is in effect not "new" for Croatia at all. From 1994 until 2001 dividends were fully exempt under the consumption-based tax model - interest adjusted profit (corporate income) tax and interest adjusted (personal) income tax.

Both countries have progressive personal income tax system (with highest marginal tax rates of $50 \%$ in Slovenia and $45 \%$ in Croatia). In Slovenia, only interests on bank current accounts are exempt (others up to $300.000 \mathrm{SIT}$ ) and capital gains are taxed at flat rate of $25 \%$. In Croatia, more capital incomes are exempt (interest on bank deposits, on securities, long term capital gains from immovable property, capital gains from securities). Other capital incomes are taxed at the different (flat) withholding rates that are either final tax burden (rents) or could be final tax burden, depending on the taxpayers' decision to file and income tax return at the end of the year or not.

\section{Degree of mitigation the economic double taxation of dividends (dividend relief) in Slovenia and Croatia}

In order to calculate dividend relief, the first ultimate burden when applying classical system (which is the benchmark to calculate the dividend relief) and 
Helena Blažić, Dženeta Bašagić

\section{Dividend Taxation: The Comparative Analysis with}

Emphasis on Slovenia and Croatia

the ultimate burden of the system in use (integration method) must be calculated.

The former is calculated as ${ }^{12}$

$\mathrm{Td}=\mathrm{td}+\mathrm{m}(1-\mathrm{td})$

where $\mathrm{Td}=$ combined corporate and personal tax on a unit of distributed corporate profits, $t d=$ corporate tax rate, $\mathrm{m}=$ marginal personal income tax rate.

For the schedular system with separate (linear, flat) tax rate on dividend income, which is achieved by the way of final withholding tax, the formula is

$T d=t d+(1-t d) w$

where $w=$ withholding (linear, flat, separate) tax rate. For the shareholders where $w=m$, the integration method (schedular system) has the same effect as the classical system (this is the case for low incomes). For Croatia this rate was 0,15 , which is the lowest marginal tax rate ${ }^{\mathbf{1 3}}$.

For the schedular system, with partial or full dividend exemption, the formula is

$$
\mathrm{Td}=\mathrm{td}+(1-\mathrm{td}-\mathrm{e}(1-\mathrm{td})) \mathrm{m}
$$

where $e=$ part of the dividend that is exempt from personal income tax. It is 0,35 for Slovenia and 1 for Croatia, where than $\mathrm{Td}=\mathrm{td}$. That is, in fact, the same effect as with $w=0$.

The dividend relief could be expressed as

Dividend relief $=\frac{T d_{c}-T d_{s}}{T d_{c}-m}$

where $_{c, s}$ denote classical system / schedular system (or any other integration method) in question.

The alternative gradual calculation and concrete examples of all the above mentioned measures (tax burdens and dividend reliefs) is presented in Appendix. By applying the stated calculations to the cases of Slovenia and Croatia, we arrive to the results presented in figures 2 and $3^{\mathbf{1 4}}$.

12 The following formulas are based on the OECD, 1991, p. 245-247 and 254-259 with the author's modifications and additions.

13 It is the formula without local surcharge (surtax). If we include it also (for the municipalities that levy it), the formula is $T d=t d+(1-t d) w+((1-t d) w) p$, where $p=$ rate of local surcharge.

14 The ultimate results using the above formulas and the examples could be slightly different due to the rounding of data at one decimal point. 
Figure 2: Dividend relief in Croatia

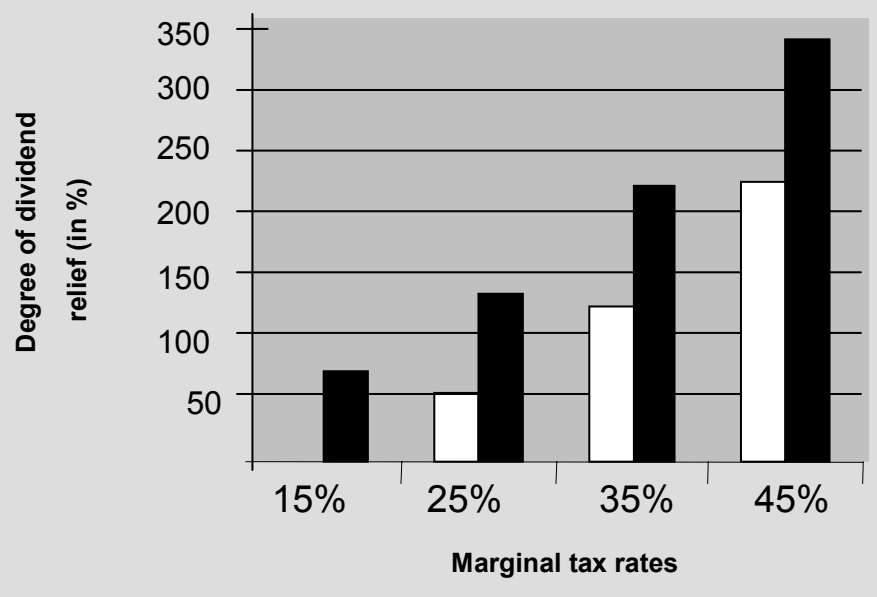

$\square$ Croatia-old method

Croatia-new method

Figure 3: Dividend relief in Slovenia

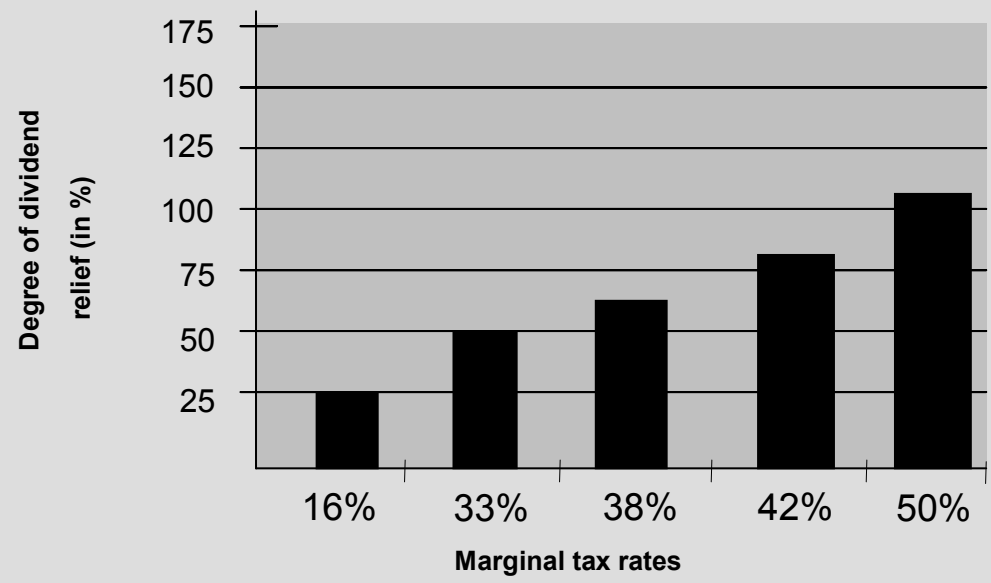




\section{Helena Blažić, Dženeta Bašagić \\ Dividend Taxation: The Comparative Analysis with \\ Emphasis on Slovenia and Croatia}

It is shown in both cases that both schedular methods, better to say schedular treatment in general, are regressive (in contrast to imputation method and other integration methods at corporate level). The benefit (dividend relief) is distributed regressively with respect to income. It rises, as income rises. This was already shown by Cnossen $(1991$, p. 12) for the tax credit method, by Blažić (2002) for the separate (linear, flat) tax for dividends and it is shown even here for the exemption method as well as tax credit method again.

\section{Conclusion}

Most tax systems have accepted the necessity to mitigate the economic double taxation of dividends. It is achieved by different methods of integration of corporate tax and personal income tax, among them the schedular treatment at the shareholder level, especially the (partial or full) dividend exemption, being gaining in importance. This is true for the new EU members and SEE as well as for old EU members and other developed countries. The former group of countries is more inclined to the full exemption than the later group.

Slovenia and Croatia both implement dividend exemption method. The exemption is 35\% in Slovenia and 100\% (full) in Croatia. Former Croatian system (which is in effect also this year) is that of separate (lower, flat, linear) tax rate on dividends, which was achieved by the final withholding tax on dividends. All methods (old and new Croatian methods and Slovenian method) have a dividend relief which is distributed regressively with respect of income (the relief rises about five times in both of the countries (indefinitely under the old method in Croatia)). This result is got by comparing tax burden under classical system (under progressive personal income tax rates) and tax burden under the schedular method in question.

It could be argued that the classical method as a benchmark for Croatia for the new Croatian system could be also calculated using the flat (linear) rate(s), since capital income that are taxed in Croatia, are mostly (in general) taxed under the different flat rates. Of course, the question then arises, which of those rates could be relevant for the comparison (maybe the rate of the interest). 


\section{Helena Blažić, Dženeta Bašagić \\ Dividend Taxation: The Comparative Analysis with Emphasis on Slovenia and Croatia}

Helena Blažić is Associate Professor at the Faculty of Economics, University of Rijeka, Croatia. She is also visiting professor at the Faculty of Economics in Split. She has got a PhD from the Faculty of Economics in Rijeka and Master's Degree from the Faculty of Economics, University in Ljubljana. Her field of interest are tax policy, comparative taxation and compliance costs of taxation.

Dženeta Bašagić is graduate student at the Faculty of Economics, University of Rijeka. Her graduate paper is about flat tax. She works as student assistant at the course Comparative Tax System and has been awarded as the best student of her generation.

\section{References}

- Blažić, H. (2002): "Ekonomsko dvostruko oporezivanje u Hrvatskoj", Ekonomski pregled, Vol. 53, No. 3-4, p. 362-390.

- Cnossen, S. (1993): "What Kind of Corporation Tax?" Bulletin for International Fiscal Documentation, Amsterdam, Vol. 47, No. 1, p. 3-16.

- Džafić, M. (2004): "Oporezivanje dohotka fizičkih lica u F BiH", Porezni savjetnik, VII, 11, p. 17-22.

- IBFD: (2005): European Tax Handbook, IBFD, Amsterdam.

- IBFD: (various years): European Tax Handbook various previous issues, IBFD, Amsterdam.

- Jacobs, O.H., Spengel, C.; Finkenzeller, M., Roche. M. (2003): “Company Taxation in the New Member States", Survey of the Tax Regimes and Effective tax Burdens for Multinational Investors, Ernst\&Young, Frankfurt am Main/Mannheim, ZEW (Zentrum fuer Europaeische Wirtschaftsforschung - Centre for European Economic Research).

- Messere, K. (1993): "Tax Policy in OECD Member Countries", IBFD, Amsterdam.

- Messere, K. (1999): "Half a Century of Changes in Taxation", Bulletin for International Fiscal Documentation, Amsterdam, 53 , 8-9, str.340-365.

- OECD: (1991): "Taxing Profits in a Global Economy", OECD, Paris.

- Croatian corporate and personal income tax acts, www.nn.hr 
Helena Blažić, Dženeta Bašagić

Dividend Taxation: The Comparative Analysis with

Emphasis on Slovenia and Croatia

\section{POVZETEK}

\section{Obdavčitev dividend: primerjalna analiza s poudarkom na Sloveniji in Hrvaški}

Problem dvojnega obdavčenja, ki se pojavi pri obdavčitvi dividend, se lahko delno ali $v$ celoti odpravi z uporabo različnih metod integracije davka od dohodka pravnih oseb in dohodnine oziroma obdavčitve dividend. Poleg klasičnega sistema (ta ne odpravlja dvojne obdavčitve, ampak v celoti obdavči najprej razdeljeni dobiček na ravni podjetja, potem pa z obdavčitvijo dividende isti dobiček še enkrat na ravni posameznika) in sistema polne integracije ( $v$ katerem je razdeljeni dobiček obdavčen samo na ravni podjetja ali samo na ravni posameznika), poznamo še sisteme, ki delno odpravljajo dvojno obdavčitev ali na ravni podjetja ali na ravni posameznika - prejemnika dividend.

Sistemi, ki na ravni podjetja odpravljajo ali zmanjšujejo dvojno obdavčitev, so bili v zadnjem času odpravljeni. Gre za sistem dvojnih stopenj davka od dohodka pravnih oseb, po katerem je dobiček podjetja, ki se razdeli delničarjem, obdavčen po nižji davčni stopnji kot zadržani dobiček. Drugi sistem, ki je na ravni podjetja lajšal dvojno obdavčitev, je bil sistem znižanja davčne osnove, saj se je davčna osnova davka od dobička znižala za določen odstotek izplačanih dividend.

V sodobnih davčnih sistemih se uporabljajo predvsem sistemi, ki na ravni posameznika v celoti ali delno odpravljajo dvojno obdavčitev. Gre za sistem vračunanja davka družbe, imenujemo ga tudi imputacijski sistem (polni ali delni) in za različne oblike cedularnih sistemov. $V$ imputacijskem sistemu se vsaj del plačanega davka od dobička družbe prizna kot olajšava pri obdavčitvi dividend, ki so bile izplačane lastniku. Družba plača davek po zakonski stopnji, olajšavo pa uveljavlja lastnik pri davčni napovedi $s \mathrm{t}$. i. obrutenjem dividende (izplačanega zneska), povečane za del davka od dobička, ki se nanaša na lastnikov delež. Ločimo polno vračunanje (pri obravnavi lastnikove obdavčitve dividend se upošteva celoten davek od dobička družbe, ki odpade na lastnikov delež) in delno vračunanje (bolj pogosto; lastniku se dovoljuje olajšava le za del pripisanega davka). Poznamo tudi tri oblike cedularnega sistema: znižanje davka pri obdavčitvi dividend (se ne uporablja več), priznavanje davčne olajšave pri 


\section{Helena Blažić, Dženeta Bašagić \\ Dividend Taxation: The Comparative Analysis with Emphasis on Slovenia and Croatia}

obdavčenju dividend in uporaba posebnih davčnih stopenj za obdavčitev dividend.

$\checkmark$ prispevku je podana primerjalna analiza obdavčitve dividend, predvsem z vidika uporabe različnih sistemov lajšanja dvojne obdavčitve dobičkov. Medtem ko "stare« članice EU še vedno uporabljajo delni imputacijski sistem (Španija, Združeno Kraljestvo in do leta 2006 Norveška) in drugi dve obliki cedularnega sistema (vse druge razen Irske, ki uporablja klasični sistem), pa "nove" države članice EU (razen Malte, ki uporablja polni imputacijski sistem) in države jugovzhodne Evrope večinoma uporabljajo cedularna sistema. Češka, Madžarska, Litva in Poljska uporabljajo sistem različnih davčnih stopenj, Estonija, Latvija in Slovaška pa sistem priznavanja davčne olajšave.

Hrvaška in Slovenija sta $v$ zadnjem času spremenili sistem obdavčitve dividend. Medtem ko je Hrvaška $v$ letu 2005 prešla iz sistema različnih stopenj na sistem davčne olajšave, se je $v$ Sloveniji zgodilo ravno obratno. Hrvaška je do leta 2005 dividende obdavčila cedularno, z nižjo davčno stopnjo (15\%), ne pa s stopnjami, ki so veljale za dohodninske razrede. Od leta 2005 pa je praktično odpravila dvojno obdavčenje razdeljenih dobičkov, saj velja za dividende pri obdavčenju z dohodnino davčna olajšava v višini $100 \%$. Slovenija je do leta 2006 pri obdavčitvi dividend priznavala davčno olajšavo $v$ višini $35 \%$ (do leta 2005 pa $40 \%$ ) ter s tem delno odpravljala dvojno obdavčitev dividend, od leta 2006 so dividende obdavčene cedularno (izločene iz dohodnine), in sicer $v$ celoti po enotni davčni stopnji $20 \%$.

Izračuni končnega davčnega bremena hipotetičnega klasičnega sistema, starih ter novih sistemov obdavčitve dividend $v$ obeh državah so pokazali, da so koristi $v$ vseh primerih porazdeljene regresivno glede na celoten dohodek posameznika. To pomeni, da imajo večje koristi tisti z višjimi dohodki. Hipotetični izračuni so pokazali, da so koristi od lajšanja dvojnega obdavčenja do petkrat višje za ljudi v najvišjem dohodninskem razredu pri novem hrvaškem in starem slovenskem obdavčenju. Še večje pa so razlike pri starem hrvaškem in novem slovenskem sistemu obdavčitve dividend. Do takih razlik pa ne prihaja v imputacijskih sistemih in drugih sistemih integracije obdavčenja razdeljenih dobičkov na ravni podjetij in posameznikov. 
Helena Blažić, Dženeta Bašagić

Dividend Taxation: The Comparative Analysis with

Emphasis on Slovenia and Croatia

\section{Appendix}

The gradual calculation of dividend relief in Croatia and Slovenia (it is assumed that all profits are distributed)

Croatia

Hypothetical classical system (without surtax)

a. Corporate level

1. Profits before corporation tax 100

2. Corporation tax $20 \% \quad 20$

b. Shareholder level

3. Income tax rate:

4. Dividend income (1-2) 80

$15 \% \quad 25 \% \quad 35 \% \quad 45 \%$

5. Income tax $(3 \times 4)$

12

80

$80 \quad 80$

Combined tax burden

6. Total tax $(2+5)$

7. Effective tax rate $(6 \cdot 1)$

$32 \quad 40$

48

56

8. Overtaxation-CO

$((7-3) \cdot 3)-113 \%$

$40 \%$

$48 \%$

$56 \%$

Note: $\mathrm{CO}$ - classical overtaxation (overtaxation if classical system is applied - this category will be used for the next calculations

Croatian model up to 2004 (2005)

Separate (lower, flat) rate (as final withholding tax)

a. Corporate level

1. Profits before corporation tax 100

2. Corporation tax $20 \% \quad 20$

b. Shareholder level

$\begin{array}{lllll}\text { 3. Income tax rate: } & 15 \% & 25 \% & 35 \% & 45 \% \\ \text { 4. Dividend income (1-2) } & 80 & 80 & 80 & 80 \\ \text { 5. Income tax (15\%) } & 12 & 12 & 12 & 12\end{array}$

c. Combined tax burden

6. Total tax $(2+5)$

32

32

32

32

7. Effective tax rate(6:1)

$32 \%$

$32 \%$

$32 \%$

$32 \%$

8. Overtaxation ((7-3):3) $\quad 113 \%$

$28 \%-8,6 \%$

$28,9 \%$

9. Tax relief (CO-8): $\mathrm{CO}$

$0 \%$

$53 \%$

$123,2 \%$

$220,4 \%$ 
Croatian model from 2005 (full dividend exemption)

a. Corporate level

1. Profits before corporation tax 100

2. Corporation tax $20 \% \quad 20$

b. Shareholder level

3. Income tax rate: $\quad 15 \% \quad 25 \% \quad 35 \% \quad 45 \%$

4. Dividend income (1-2) $\quad 80 \quad 80 \quad 80 \quad 80$

5. Income tax (full exemption) - $\quad$ - $\quad$ -

c. Combined tax burden

6. Total tax $(2+5) \quad 20 \quad 20 \quad 20 \quad 20$

7. Effective tax rate(6:1) 20\% 20\% 20\% $20 \%$

8. Overtaxation ((7-3):3) $\quad 33,3 \% \quad-20,0 \% \quad-42,9 \% \quad-55,6 \%$

9. Tax relief (CO-8):CO $\quad 70,5 \% \quad 133,0 \% \quad 215,9 \% \quad 331,7 \%$

Slovenia - Hypothetical classical system

a. Corporate level

1. Profits before corporation tax 100

2. Corporation tax $25 \% \quad 25$

b. Shareholder level

3. Income tax rate: $\quad 16 \% \quad 33 \% \quad 38 \% \quad 42 \% \quad 50 \%$

4. Dividend income (1-2) $75 \quad 75 \quad 75 \quad 75 \quad 75$

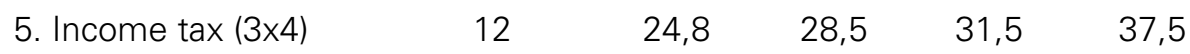

c. Combined tax burden

6. Total tax $(2+5) \quad 37 \quad 49,8 \quad 53,5 \quad 56,5 \quad 62,5$

7. Effective tax rate $(6: 1) \quad 37 \% \quad 49,8 \% \quad 53,5 \% \quad 56,5 \% \quad 62,5 \%$

8. Overtaxation ((7-3):3) $\quad 131,3 \% \quad 50,9 \% \quad 40,8 \% \quad 34,5 \% \quad 25 \%$

Note: advance payment of $25 \%$ withholding tax on dividends not included, since this tax is not final (it is deducted from the final tax due, when income tax return is submitted) 
Helena Blažić, Dženeta Bašagić

Dividend Taxation: The Comparative Analysis with

Emphasis on Slovenia and Croatia

Slovenian model (partial dividend exemption)

a. Corporate level

1. Profits before corporation tax 100

2. Corporation tax $25 \% \quad 25$

b. Shareholder level

3. Income tax rate: $\quad 16 \% \quad 33 \% \quad 38 \% \quad 42 \% \quad 50 \%$

4. Dividend income (1-2) $\quad 75 \quad 75 \quad 75 \quad 75 \quad 75$

$\begin{array}{llllll}\text { 5. Exemption (35\%) } & 26,3 & 26,3 & 26,3 & 26,3 & 26,3\end{array}$

$\begin{array}{llllll}\text { 6. Taxable dividend (4-5) } & 48,7 & 48,7 & 48,7 & 48,7 & 48,7\end{array}$

7. Income tax (3x6) $\quad 7,8 \quad 16,1 \quad 18,5 \quad 20,5 \quad 24,4$

c. Combined tax burden

8. Total tax (2+7) $\quad 32,8 \quad 41,0 \quad 43,5 \quad 45,5 \quad 49,4$

9. Effective tax rate $(8: 1) \quad 32,8 \% \quad 41,0 \% \quad 43,5 \% \quad 45,5 \% \quad 49,4 \%$

10. Overtaxation ((9-3):3) $\quad 105 \% \quad 24,2 \% \quad 14,5 \% \quad 8,3 \% \quad-1,2 \%$

11. Dividend relief (CO-10):CO $\quad 20,0 \% \quad 52,4 \% \quad 62,9 \% \quad 75,9 \% \quad 105 \%$

Slovenian model 2 (from 2006)

Separate (lower, flat) rate (as final withholding tax)

a. Corporate level

1. Profits before corporation tax 100

2. Corporation tax $25 \%$

b. Shareholder level

3. Income tax rate: $\quad 16 \% \quad 33 \% \quad 38 \% \quad 42 \% \quad 50 \%$

4. Dividend income (1-2) $\quad 75 \quad 75 \quad 75 \quad 75 \quad 75$

5. Income tax (20\%) $\quad 15 \quad 15 \quad 15 \quad 15 \quad 15$

c. Combined tax burden

6. Total tax (2+5) $\quad 40 \quad 40 \quad 40 \quad 40 \quad 40$

7. Effective tax rate(6:1) $\quad 40 \% \quad 40 \% \quad 40 \% \quad 40 \% \quad 40 \%$

8. Overtaxation ((7-3):3) $\quad 150 \% \quad 21,2 \% \quad 5,3 \% \quad-4,8 \% \quad-20 \%$

9. Tax relief (CO-8):CO $\quad-14,2 \% \quad 58,3 \% \quad 87, \% \quad 113,9 \% \quad 180 \%$ 